\section{INFORMATION}

U.S. DEPARTMENT OF ENERGY

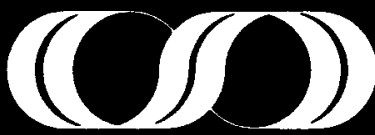

CONSERVATION AND

RENEWABLE ENERGY INQUIRY AND REFERRAL SERVICE

\title{
Geothermal Energy Technology Program Summary \\ $\mathrm{DOE} / \mathrm{CE}--0111$
}

DE85 013101

\section{Introduction}

The goal of the national energy policy is to foster an adequate supply of energy at reasonable prices. This policy recognizes that "adequate supply" requires flexibility, with no undue reliance on any single source of supply. The goal of "reasonable prices" suggests economic efficiency so that consumers, individuals, commercial and industrial users alike, are not penalized by economic rigidities introduced into the system by governmental regulation or subsidy. The strategies for achieving this energy policy goal are:

- to minimize Federal regulation in energy pricing while maintaining public health and safety and environmental quality; and

- to promote a balanced and mixed energy resource system through research and development.

\section{Technical Description}

Geothermal energy involves the use of the natural heat of the earth either directly or through conversion to other usable forms of energy. There are four major types of resources of concern to the Federal Geothermal Program. They are, in order of technological readiness: hydrothermal, geopressured, hot dry rock, and magma.

Hot water and steam trapped in fractured, porous reservoirs below the earth's surface are considered hydrothermal resources. At high temperature, this energy may be used to generate electricity, whereas moderate and low temperature resources may be utilized for industrial process heating, residential and commercial space heating, and domestic hot water.

Geopressured resources consist of water saturated with methane gas at moderately high temperatures and pressures. This resource offers three sources of usable energy: methane, heat, and mechanical Hot dry rock resources contaith int or no water. The heat is extracted from them by drilling wells and fracturing the rock to create a circulation loop. Liquid is injected into the formation, is heated by the rock as it moves along the fractures, and is extracted at a second well.

The fourth geothermal resource, magma, consists of molten or partially molten rock at extremely high temperatures and at accessible depths (less than $10 \mathrm{~km}$ ) in the earth's crust.

\section{Progress to Date}

Technology developments supported by the U.S. Department of Energy (DOE) have resulted in the commercial availability of the following items:

- magnetotelluric and passive seismic exploration techniques;

- precipitators/clarifiers and scale inhibitors to handle high salinity, corrosive brines;

- well head-size flash, total flow, and direct contact heat exchanger systems;

- high temperature elastomers and polymer concretes;

- improved drag bit and roller bit drills, using polycrystalline diamonds and new seals and bearings;

reswater- and mud-driven turbodrills oftirectional drilling:

- Ifitating water-jet cleaning for pipes and heat exchangers; and

- high temperature electronics and sensors for well logging.

In addition, major progress has been made in resolving technical problems in other areas. For example:

- reservoir models for predicting production capacity and longevity are beginning to be successfully utilized;

- federal and state air quality concerns are being met;

- binary systems, low-cost materials and components, and chemical treatments are becoming available for generating facilities; 


\section{DISCLAIMER}

This report was prepared as an account of work sponsored by an agency of the United States Government. Neither the United States Government nor any agency Thereof, nor any of their employees, makes any warranty, express or implied, or assumes any legal liability or responsibility for the accuracy, completeness, or usefulness of any information, apparatus, product, or process disclosed, or represents that its use would not infringe privately owned rights. Reference herein to any specific commercial product, process, or service by trade name, trademark, manufacturer, or otherwise does not necessarily constitute or imply its endorsement, recommendation, or favoring by the United States Government or any agency thereof. The views and opinions of authors expressed herein do not necessarily state or reflect those of the United States Government or any agency thereof. 


\section{DISCLAIMER}

Portions of this document may be illegible in electronic image products. Images are produced from the best available original document. 
- approximately 600 commercial geothermal wells have been drilled; $:$;

technical feasibility of producing geopressured brines; extracting methane, and reinjecting the spent fluid has been established;

- large permeable fracture systems have been created in hot dry rock formations;

- scientific feasibility of extracting heat from magma sources has been determined;

- national maps of potential resources have been produced, with detailed maps for 17 Western states;

- improved geophysical techniques have expedited the discovery of geothermal reservoirs.

The DOE Geothermal Program is now focused on providing the necessary scientific and engineering information to close the remaining technology gaps; and to reduce the cost of exploiting the more abundant moderate-temperature hydrothermal resources. The technology base resulting from this work will also have application to geopressured, hot dry rock, and magma resources.

\section{Federal/Industry Cooperation}

DOE's Geothermal and Hydropower Technologies Division (GHTD) has two cooperative geothermal projects with industry in progress and others are planned. A. 45 megwatt (MW) binany plant at Heber, California, is being constructed under a cooperative agreement between DOE and San Diego Gas and Electric Co. Other participants in this project include the Electric Power Research Institute, the Imperial Irrigation .District and Southern California Edison Co. The purpose of this plant is to determine the economic feasibility of commercial power generation with the moderate temperature $\left(150-200^{\circ} \mathrm{C}\right)$ resource. Scheduled for completion in 1985 , the project is on schedule and within budget.
In addition, DOE is supporting wellfield development and engineering design for the construction of $a$ hybrid binary plant at Hoñoy Lake, California. The $87 \mathrm{MW}$ - plant will operate on both a low temperature ( $\left.\angle 150^{\circ} \mathrm{C}\right)$ hydrothermal fluid and combustion of wood wastes. The wastes, generated by adjacent timber operations, will be collected by GeoProducts, builder of the plant. If a system of this type is determined to be economically feasible, the way would be opened for greater use of low-grade hydrothermal resources.

The Electric Power Research Institute has committed funds for a cooperative experiment to investigate technical system parameters of well head power generation utilizing the hydraulic and thermal energy components of geopressured resources. DOE will modify a geopressurre design well site to serve as a test bed.

GeoProducts shared the cost.

A DOE/industry cost-shared drilling project is to begin in FY 1985.

GHTD will work with industry representatives to select and define advanced drilling concepts that incorporate all available improvements prevviously funded by DOE. The cost of fabrication and field testing will be shared with industry.

\section{Program Focus}

\section{Purpose}

The purpose of GHTD's program is to concentrate geothermal energy. research and development in areas where the incentives for, and availability of, private investment are severely limited. In these areas, competitive rates of return on technology development investments cannot be realized by private firms due to the high-risk nature of the R\&D investment, lack of an adequate market and/or service infrastructure, or the exceptionally long lead times required before returns begin.

\section{Goals and Objectives}

Within the guidelines of the National Energy Policy Plan (NEPP-IV), the goal of GHTD's program is to help build a technology base that will enable the private sector to economically develop the various forms of geothermal resources

\section{Strategy}

GHTD's program represents $\mathbf{a}$ balanced mix of applied research, resource definition, and sưfficient engineering development to establish a technical base to support private sector investment. Specific efforts are designed to develop the engineering tools and acquíî the technical data necessary to reduce the development risks perceived by private sector developers.

\section{Research Plan}

The Federal geothermal energy research plan includes six major areas:

- Hydrothermal Industrialization;

- Geopressured Resources;

- Hot Dry Rock;

- Hydrothermal Research;

- Hard Rock Penetrative Research; and

\section{- Magma Energy Extraction.}

\section{Hydrothermal \\ Industrialization}

The Hydrothermal Industrialization Sub-Program is composed of three activities: Resource Definition, Low Enthalpy Systems, and Facilities. The objectives of this sub-program are to encourage state participation in assessing high-temperature reservoirs; evaluate the engineering and economic viability of low enthalpy (non-electric) systems; determine the technical and economic viability of 1) generating electric power with moderate temperature $\left(150^{\circ} \mathrm{C}-200^{\circ} \mathrm{C}\right)$ hydrothermal resources, and 2) with a low: temperature $\left(<105^{\circ} \mathrm{C}\right)$ resource in combination with another energy source in a hybrid plant. 


\section{Geopressured Resource}

The overall goal of the Geopressured Resource Subprogram is to establish the general existence and determine the characteristics of the geopressured geothermal resource and to determine the optimum means of energy recovery through the development of a technology base for later use by private industry. In addition, the basic technology for extracting methane and thermal energy has been tested.

The FY 1985 program will provide comprehensive analysis and archiving of long duration flow test data from the geopressured 'design' wells, and continue design well tests. The flow tests will include a cooperative experiment with industry to investigate technical system parameters related to generation of wellhead electric power from the hydraulic and thermal energy components of geopressured brine streams.

\section{Hot Dry Rock Research}

The objective of the Hot Dry Rock Research Program is to determine the technical and economic feasibility of extracting geothermal heat from hot dry rock resources. Field experiments at Fenton Hill, New Mexico, have proven the energy extraction concept of connecting two wells in hot dry rock with a manmade fracture system.

The FY 1985 program will verify the potential of this geothermal energy extraction technique. In addition, the feasibility of consturcting a multiple-fracture, large scale reservoir with a project life of at least ten years will be evaluated.

\section{Hydrothermal Research}

In FY 1985, research efforts will continue in the areas of brine injection technology, reservoir definition technology, and heat cycle research. New activities will be initiated under the permeability enhancement, caldera reservoir investigations, Geothermal Test Facility (including materials testing), and deep scientific drilling tasks.

\section{Hard Rock Penetration Research}

The objective of the Hard Rock Penetration Research activity is to facilitate geothermal energy utilization by ensuring the availability of economically and technologically suitable materials and techniques to the geothermal drilling industry. In addition to the technical activities associated with this program, the additional effort to transfer these developments to private industry where they can be utilized to reduce costs is an important aspect of the program goal.

In FY 1985, research tasks will continue in the following areas:

a) Mechanics of Rock Penetration - The objectives of this task are to measure the parameters associated with rock penetration by crushing, spalling, shearing, erosion, and shock loading under simulated geothermal downwell conditions, and to develop a theoretical or empirical correlation between predicted and measured performance of rock penetration devices.

b) Borehole Mapping - The objective of this task is to provide techniques and instrumentation for characterizing geothermal wellbores and improving mapping accuracies.

c) Drilling Instrumentation - The objective is to develop downhole instrumentation and sensors for directional monitoring while drilling, to enable the transmission of data to the surface.

d) Drilling Instrumentation - The objective is to identify, evaluate, design, and test all candidate techniques displaying advanced methods for breaking and removal of rock, and having potenial for development into an advanced drilling system that could lead to a 25-50 percent geothermal well cost reduction.

e) Drilling Fluid Loss Control The objective is to develop new effective materials for fluid loss control during drilling and completion in high temperature environments, including seeking one that will degrade after it has performed its function.

f) DOE-Industry Cost-Shared Drilling System - The objective is to provide industry with a geothermal drilling system prototype that incorporates the best of available technology.

\section{Magma Energy Extraction}

This activity involves the identification of reservoir prospects for economic extraction of magma energy. The goal is to verify the viability of exploring potentially vast magma resources. The U.S. Geological Survey has estimated that the size of the molten and near-molten rock resources within the $10 \mathrm{kms}$ of the earth's surface is between 50,000 to 500,000 quads in terms of available heat energy; there is, therefore, a need to explore the extent of exploitable magma energy in the U.S.

The FY 1985 program will (1) develop preliminary characterization of candidate magma reservoirs identified in the previous year, (2) initiate the development of feasible designs for heat exchangers and pumps for use in energy extraction, and (3) start the selection of materials suitable for use in the equipment designed to extract magma energy. 


\section{DIVISION OF GEOTHERMAL AND HYDROPOWER TECHNOLOGIES BUDGET SUMMARY (\$000)}

Hydrothermal Resources

Geopressured Resources

Geothermal Technology Development Geothermal Technology Transfer

Other

TOTAL
FY 1983

$\$ 32,983$

8,400

14,958

0

1,250

$\$ 57,591$
FY 1984

$\$ 2,000$

5,000

22,359

100

1,000

$\$ 30,459$
FY 1985

$\$ 1,000$

5,500

23,556

1,000

1,031

$\$ 32,087$

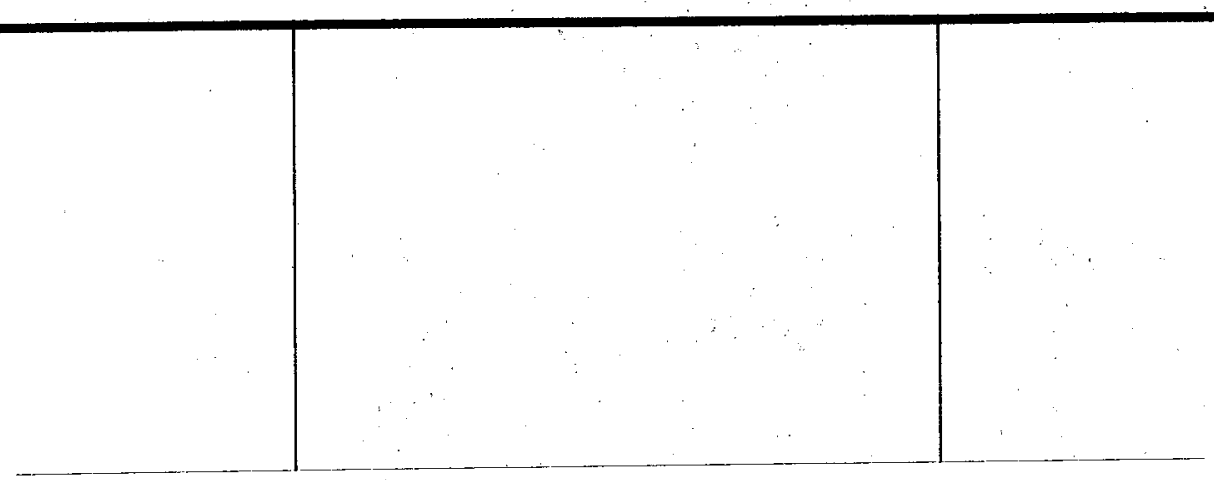

DISCLAIMER

This report was prepared as an account of work sponsored by an agency of the United States Government. Neither the United States Government nor any agency thereof, nor any of their employees, makes any warranty, express or implied, or assumes any legal liability or responsibility for the accuracy, completeness, or usefulness of any information, apparatus, product, or process disclosed, or represents that its use would not infringe privately owned rights. Reference herein to any specific commercial product, process, or service by trade name, trademark, manufacturer, or otherwise does not necessarily constitute or imply its endorsement, recommendation, or favoring by the United States Government or any agency thereof. The views and opinions of authors expressed herein do not necessarily state or reflect those of the United States Government or any agency thereof. 